\title{
The Price Puzzle: An Update and a Lesson
}

\author{
Michael J. Dueker
}

A fundamental tenet of monetary policymaking is that a surprise increase in the short-term interest rate will lower price inflation from what it otherwise would have been. Thus, it has been disconcerting to macroeconomists that many empirical estimates of the relationship between the federal funds rate and inflation have suggested that a surprise interest rate hike is followed immediately by a sustained increase in the inflation rate. This result has become known as the "price puzzle," starting with Eichenbaum (1992). Hanson (2004) showed that it is not easy to explain away the price puzzle, especially in the pre-1980 period. The attached chart highlights circumstances in which the price puzzle flourished; specifically, it shows the tendency of the federal funds rate to precede change in inflation in the same direction during the 1970s.

Interpretations of the price puzzle can differ in an important aspect: A conventional view is that nobody should believe that surprise interest rate hikes are ever inflationary in reality. According to this view, any empirical finding of the price puzzle is necessarily a false reading and a sign of a problem with the empirical model that generated such a result. A relatively new explanation for the price puzzle admits the possibility that surprise interest rate hikes really could be inflationary in some circumstances.

The view that the price puzzle is a genuine phenomenon-especially in the pre-1980 period-can be based on indeterminacy. Loosely speaking, an economy's characteristics correspond to indeterminacy when there is no way to identify the exact sources of forecast errors (for inflation and GDP, for example) in terms of clearly identifiable sources of shocks (such as surprise changes in the federal funds rate and productivity surprises). In general, it is possible to show in a macroeconomic model that some combinations of characteristics (such as how risk-averse people are, how sticky prices are updated, and how monetary policy is set) pertain to "determinacy" and others pertain to "indeterminacy."

Lubik and Schorfheide (2003) provided the necessary tools to allow for empirical estimates of an economy under indeterminacy. Hence, only recently have macroeconomists been able to explore how closely the data from a given time period conform to determinacy or indeterminacy. Belaygorod and Dueker (2006) estimate a model of the U.S. economy that also attempts to discern the precise period when indeterminacy was relevant. Their estimates suggest that the indeterminacy period was roughly from 1972 through 1981. Importantly for the price puzzle, the model estimates imply that in this period of indeterminacy, inflation would rise immediately and in a sustained fashion in response to an interest rate hike. Reassuringly for monetary policymakers, the model estimates for both determinacy periods- before 1972 and after 1981-suggest that increases in the federal funds rate unambiguously help rein in inflation.

In the type of model Belaygorod and Dueker estimated, indeterminacy occurs when monetary policy is too passive in terms of raising the federal funds rate in response to an increase in inflation. Thus, one understanding of the Great Inflation of the 1970s and early 1980s that can come from the indeterminacy explanation of the price puzzle is that monetary policymakers have a devil of a time extricating the economy from indeterminacy. Once people in the economy come to believe in the price puzzle - that interest rate hikes are inflationaryhow do monetary policymakers persuade people to believe again in the determinacy regime, wherein interest rate hikes would reduce inflation? The lesson policymakers seem to have learned is to avoid this trap in the first place by remaining active inflation fighters in order to preserve people's beliefs in determinacy.

Belaygorod, Anatoliy and Michael Dueker. "Timing Transitions Between Determinate and Indeterminate Equilibria in DSGE Models: Benefits and Implications." Working Paper 2006-025, Federal Reserve Bank of St. Louis.

Eichenbaum, Martin. "Interpreting Macroeconomic Time Series Facts: The Effects of Monetary Policy: Comments.” European Economic Review, June 1992, 36, pp. 1001-11.

Hanson, Michael. “The 'Price Puzzle' Reconsidered." Journal of Monetary Economics, October 2004, 51, pp. 1385-413.

Lubik, Thomas and Schorfheide, Frank. "Computing Sunspot Equilibria in Linear Rational Expectations Models." Journal of Economic Dynamics and Control, November 2003, 28, pp. 273-85.

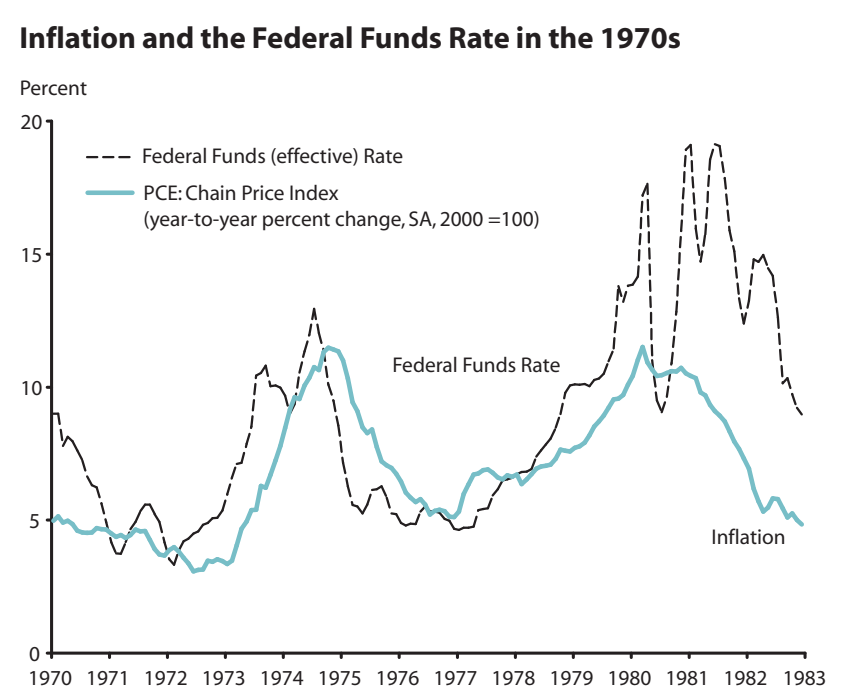

